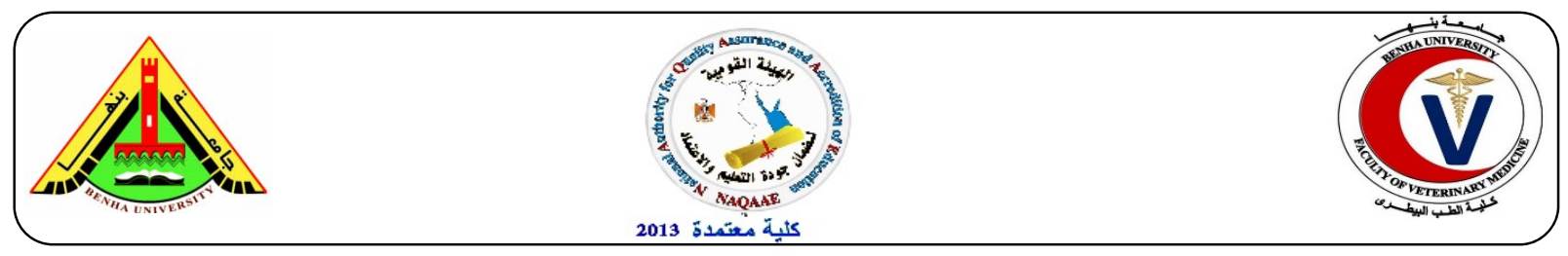

\title{
Bacterial evaluation of vacuum packaged meat products.
}

\author{
Shaltout, F.A. ${ }^{a}$, Zakaria, I.M. ${ }^{\text {, }}$ Lamiaa, M. lotfy ${ }^{\mathrm{c}}$, Ibrahim, I. Ahmed ${ }^{\mathrm{d}}$. \\ ${ }^{\mathrm{a}}$ Food Control Dept., Fac. Vet. Med., Benha Univ., ${ }^{\mathrm{b}}$ Animal health research institute, Doki, Giza. ${ }^{\mathrm{c}}$ Home Economics \\ Department., Fac. Specific education., Kafr Elshiekh Univ., ${ }^{d}$ microbiology department., Elborg medical lab.
}

\begin{abstract}
A B S T R A C T
The purpose of this study to evaluate the microbiological quality of vacuum packaged meat product samples (luncheonsausage) collected from different markets in Qalyobia governorate (30 of each). The obtained results indicated that the mean values of APC, anaerobic plate count and Enterobacteriacea counts was $2.1 \times 10^{6} \pm 1.5 \times 10^{6}, 1.5 \times 10^{7} \pm 3.5 \times 10^{6} \&$ $1.7 \times 10^{4} \pm 3.9 \times 10^{3} \mathrm{cfu} / \mathrm{g}$ for sausage and $2.9 \times 10^{5} \pm 2.6 \times 10^{4}, 2.4 \times 10^{5} \pm 2.5 \times 10^{4} \& 2 \times 10^{5} \pm 2 \times 10^{4} \mathrm{cfu} / \mathrm{g}$ for luncheon, respectively. Isolation and identification of some food poisoning bacteria were carried out. Salmonella, Staphylococci, and Clostridium perfringens were isolated and identified and the incidence was $10 \%, 6.6 \%$ and $33.3 \%$ for sausage and $3.3,10 \% \& 43.3 \%$ for luncheon, respectively. Contamination of food by handlers is the most common cause of the presence of microorganisms which indicate a bad hygienic measure applied through different stages of food preparation, handling and serving.
\end{abstract}

Key Words: vacuum, sausage, luncheon, salmonella

(http://www.bvmj.bu.edu.eg)

(BVMJ-31(2): 189-195, 2016)

\section{INTRODUCTION}

Meat products such as sausage, luncheon are gaining popularity because they represent quick easily prepared meat meals and solve the problem of the shortage in fresh meat of high price which is not within the income of large numbers of families. Microorganisms may contaminate meat products during a long chain of processing from the time of preparation, handling, processing, distribution and storage as well as marketing. Such contamination may render the products of inferior quality or even unfit for human consumption and at times may constitute a public health hazard. Possibility of contamination of meat products with food poisoning bacteria especially Salmonella organisms has been extensively reported (Reham, 2004). Salmonella are found worldwide and universally recognized as zoonotic agent. The primary habitat of salmonella is the intestinal tract of animals and humans. Additionally, salmonella cause illness by means of infection, as it multiplies in the intestine, colonizes and subsequently invades the intestinal tissue, producing an enterotoxin which causing inflammatory reaction and diarrhea (ICMSF, 2006). Also, Clostridium perfringens is one of the most widespread pathogenic bacteria in the environment and is commonly found (although in low numbers) in the gastrointestinal tract of healthy animals, from where it generally contaminates animal carcass during slaughtering (Aberle et al., 2001). Farther, staphylococcal food poisoning is one of major concern in public health programs worldwide. Staphylococcus aureus is a leading cause of gastroenteritis result from consumption of meat in which enterotoxigenic Staphylococci have grown and produced enterotoxins. Staphylococcal enterotoxins are considered potential biological threat because of their stability at high temperature $\left(100^{\circ} \mathrm{C}\right.$ for $1 \mathrm{hr}$.) and their ability to incapacitate individuals for several days to two weeks (Bhatia and Zahoor, 2007).

Therefore, bacterial evaluation of vacuum packaged meat products (luncheon -sausage) was the purpose of current study to detect aerobic and anaerobic as well as enteric bacteria.

\section{MATERIAL AND METHODS}

\subsection{Collecting of samples:}

A grand Total of 60 random samples of sausages and luncheon ( 30 of each) were collected from different markets in Qalyobia governorate. 
The collected samples were kept in separate sterile plastic bags and transferred directly to the laboratory of bacteriology in an ice box under complete aseptic conditions without delay, to be bacteriology examined.

\subsection{Preparation of samples: (APHA, 2001)}

25 grams of each sample were weighed and transferred into a sterile homogenizer flask containing $225 \mathrm{ml}$ of $0.1 \%$ sterile buffered peptone water then homogenized at $2000 \mathrm{rpm}$ for 1-2 min. to provide a homogenate of $1 / 10$ dilution, one $\mathrm{ml}$ from the original dilution was transferred to another sterile tube containing $9 \mathrm{ml}$ of $0.1 \%$ sterile buffered peptone water and mixed well to make the next dilution, from which further decimal serial dilutions were prepared.

\subsubsection{Aerobic Plate Count (ICMSF, 1996)}

One $\mathrm{ml}$ from each of the previously prepared serial dilutions was transferred into two separate sterile petri dishes, using pour plate method, to which approximately $15 \mathrm{ml}$ of sterile melted and tempered plate count agar $\left(45^{\circ} \mathrm{C}\right)$ were added. After through mixing, the incubated plates were allowed to solidify before being incubated at $27{ }^{\circ} \mathrm{C}$ for $24 \mathrm{hr}$. The aerobic plate count per gram calculated on plates containing 20-200 colonies was counted and each count was recorded separately.

\subsubsection{Total Enterobacteriacea Count (ISO, 2004)}

From each of the previously prepared serial dilutions, $0.1 \mathrm{ml}$ were poured into duplicate set of petri dishes, previously inoculated with $10 \mathrm{ml}$ of sterile Violet Red Bile Glucose agar medium (VRBG). Then after evenly similar equal mixing, cover layer (tempered promptly to about $45^{\circ} \mathrm{c}$ ) of approximately $5 \mathrm{ml}$ of (VRBG) agar was poured overall the plates. After thorough mixing the inoculated plates were allowed to solidify at room temperature before being inoculation. The plates were incubated at $27{ }^{\circ} \mathrm{C}$ for 24 hours. All purple suspected colonies surrounded by a purple halo were counted, the Enterobacteriaceae count / g was calculated.

\subsubsection{Confirmatory test (ICMSF, 1996)}

Two typical colonies were streaked into plates of Violet Red Bile Glucose agar and incubated at 25 - 27 'for 20 - 24 hours, from which two colonies surrounded by purple precipitation zone were separately streaked onto slants of nutrient agar. The culture was inoculated into tubes of Glucose medium. The latter was covered with a sterile mineral oil then incubated at $27{ }^{\circ} \mathrm{C}$ for $20-24$ hours. Oxidase test was carried out from the belonging to Enterobacteriaceae when the oxidase test was negative, while the glucose broth was turned to yellow.

\subsubsection{Anaerobic Bacterial Count (Roberts et al.,1995):}

One $\mathrm{ml}$ from each of previously prepared serial dilution was spread into reinforced clostridial agar media. The plates were then incubated in upright position in anaerobic gar (Mackintosh jar) at $27^{\circ} \mathrm{C}$ for $24 \mathrm{hr}$.The suspected plates were selected and counted, and the results were interpreted as colony forming units (cfu) per gram of the samples.

\section{RESULTS:}

It is evident from the result recorded in table (1) that the APC of the examined samples of vacuum packaged meat products ranged from $1.1 \times 10^{3}$ to $4.5 \times 10^{7}$ with an average of $2.1 \times 10^{6} \pm 1.5 \times 10^{6}$ for sausage and $1.1 \times 10^{5}$ to $6.2 \times 10^{5}$ with an average of $2.9 \times 10^{5} \pm 2.6 \times 10^{4}$ for luncheon.Table (2) indicated that total anaerobic plate count of the examined samples of vacuum packaged meat products was $1.1 \times 10^{5}$ to $7.1 \times 10^{7}$ with an average of $1.5 \times 10^{7} \pm 3.5 \times 10^{6}$ for sausage and $1.2 \times 10^{5}$ to $4.2 \times 10^{5}$ with an average of $2.4 \times 10^{5} \pm 2.5 \times 10^{4}$ for luncheon.

Also, Table (3) revealed the total Enterobacteriacea count of the examined samples of vacuum packaged meat products was $3.6 \times 10^{2}$ to $7.8 \times 10^{4}$ with an average $1.7 \times 10^{4} \pm 3.9 \times 10^{3}$ for sausage and $1.1 \times 10^{5}$ to $3.5 \times 10^{5}$ with an average $2 \times 10^{5} \pm 2 \times 10^{4}$ for luncheon samples. Tables (4) revealed that the incidence and serotyping of Salmonella isolated from the examined samples by $10 \%$ for sausage and $3.3 \%$ for luncheon which identified serologically as S.typhimurium (1\%) and S.entretidis (2\%) .

Table (5) referred to the C.perfringens isolated from the examined vacuum packaged meat samples with $33.3 \%$ for sausage and with $43.3 \%$ for luncheon. Moreover, Table (6) reported the incidence of Lecithinase +ve strains in the examined samples of sausage were 7 of $10(70 \%)$ of $C$. perfringens and Lecithinase -ve strains were 3 of $10(30 \%)$. Lecithinase +ve strains in the examined samples of luncheon were 10 of 13 $(77 \%)$ and Lecithinase -ve strains were 3 of 13 (23\%).

The results reported in table (7) showed that $+v e$ lecithinase strains of C.perfringens isolates were typing into type A,B,C and D toxins. Type A appeared in $70 \%$ of +ve Lecithenase in sausage samples and $100 \%$ in luncheon samples and B, C, 
Table (1): Aerobic Plate Count (APC) of the examined vacuum packaged meat products samples ( $\mathrm{n}=30$ of each)

\begin{tabular}{lccccc}
\hline Samples & Positive samples & Minimum & Maximum & Mean \pm SE \\
\hline & NO. & $\%$ & & & \\
Sausage & 30 & 100 & $1.1 \times 10^{3}$ & $4.5 \times 10^{7}$ & $2.1 \times 10^{5} \pm 1.5 \times 10^{6}$ \\
Luncheon & 30 & 100 & $1.1 \times 10^{5}$ & $6.2 \times 10^{5}$ & $2.9 \times 10^{5} \pm 2.6 \times 10^{4}$ \\
& \multicolumn{5}{c}{ S.E* } \\
\hline \multicolumn{5}{c}{ standard error of mean }
\end{tabular}

Table (2): Anaerobic Plate count of the examined vacuum packaged meat products samples ( $\mathrm{n}=30$ of each).

\begin{tabular}{|c|c|c|c|c|c|}
\hline Samples & \multicolumn{2}{|c|}{ Positive samples } & Minimum & Maximum & Mean $\pm \mathrm{SE}$ \\
\hline & NO. & $\%$ & & & \\
\hline Sausage & 18 & 60 & $1.1 \times 10^{5}$ & $7.1 \times 10^{7}$ & $1.5 \times 10^{7} \pm 3.5 \times 10^{6}$ \\
\hline Luncheon & 21 & 70 & $1.2 \times 10^{5}$ & $4.2 \times 10^{5}$ & $2.4 \times 10^{5} \pm 2.5 \times 10^{4}$ \\
\hline
\end{tabular}

Table (3): Enterobacteriacae Plate Count of the examined vacuum packaged meat products samples ( $\mathrm{n}=30$ of each).

\begin{tabular}{llllll}
\hline samples & Positive samples & Minimum & Maximum & Mean \pm SE \\
\hline \multirow{5}{*}{ Sausage } & NO. & $\%$ & & & \\
Luncheon & 22 & 73.3 & $3.6 \times 10^{2}$ & $7.8 \times 10^{4}$ & $1.7 \times 10^{4} \pm 3.9 \times 10^{3}$ \\
& 20 & 66.6 & $1.1 \times 10^{5}$ & $3.5 \times 10^{5}$ & $2.0 \times 10^{5} \pm 2 \times 10^{4}$ \\
\hline \multicolumn{5}{c}{ S.E* $=$ standard error of mean. }
\end{tabular}

Table (4): incidence of Salmonella spp., Staph aureus and Clostridium perfringens species in the examined samples of vacuum packaged meat products ( $\mathrm{n}=30$ of each).

\begin{tabular}{lcccc}
\hline & \multicolumn{3}{c}{ Sausage } & \multicolumn{1}{r}{ luncheon } \\
\cline { 2 - 5 } $\begin{array}{l}\text { Examined } \\
\text { samples }\end{array}$ & NO. & $\%$ & NO. & $\%$ \\
\hline $\begin{array}{l}\text { Salmonella spp } \\
\text { Staph. aureus }\end{array}$ & 3 & 10 & 1 & 3.3 \\
Clostridium perfringens & 10 & 33.3 & 13 & 43.3 \\
\hline
\end{tabular}


Table (5): Serotyping of salmonella spp isolated from examined samples of vacuum packaged meat products $(n=30$ of each).

\begin{tabular}{lcccc}
\hline \multirow{2}{*}{ Serotype } & Sausage & Luncheon & \multicolumn{3}{c}{ Antigenic structure } \\
\cline { 4 - 5 } & & & $\mathrm{O}$ & $\mathrm{H}$ \\
\hline S.typhimurim & 1 & 1 & $1 ; 1,4[5], 12$ & $\mathrm{i}: 1,2$ \\
S.Entritidis & 2 & 2 & 1.9 .12 & $9, \mathrm{~m}: 1,7$ \\
\hline
\end{tabular}

Table (6): incidence of lecithinase positive strains of clostridium perfringens in the examined samples of vacuum packaged meat products $(\mathrm{n}=30$ of each).

\begin{tabular}{lcccccc}
\hline \multirow{2}{*}{ sample } & $\begin{array}{c}\text { NO. examined } \\
\text { samples }\end{array}$ & $\begin{array}{c}\text { NO. positive } \\
\text { samples }\end{array}$ & $\begin{array}{c}\text { Lecithinase } \\
\text { positive }\end{array}$ & \multicolumn{2}{c}{$\begin{array}{l}\text { Lecithinase } \\
\text { Negative }\end{array}$} \\
\cline { 3 - 7 } & & & NO. & $\%$ & NO. & $\%$ \\
\hline Sausage & 30 & 10 & 7 & 70 & 3 & 30 \\
Luncheon & 30 & 13 & 10 & 77 & 3 & 23 \\
\hline
\end{tabular}

Table (7): typing of lecithinase positive of Clostridium perfringens isolated from the examined samples of vacuum packaged meat products ( $\mathrm{n}=30$ of each).

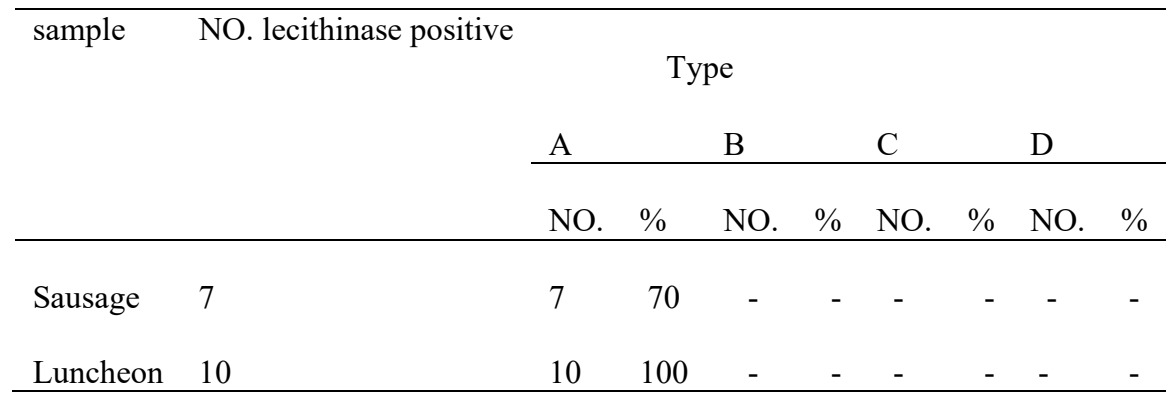

D not detected. Tables (4) reported that Staph aureus was isolated from $6.6 \%$ for sausage and $10 \%$ for luncheon.

\section{DISCUSSION}

Meat is considered as an important source of protein and a potential source of a disease if not properly prepared. If not good hygienic practices applied especially during preparation, handling and serving of meat for large groups of people, it will provide opportunities for the spread of food borne disease. So, the safety and hygienic quality of food determined by the presence of microorganisms. The total aerobic plate count gives an idea about the hygienic measures applied through receiving, handling and preparation of meat meals. So, it is the most reliable method for detection of sanitary levels of proper treatment of these food stuffs. It is evident from the results recorded in table (l) that the APC of the examined samples of vacuum packaged meat products ranged from $1.1 \times 10^{3}$ to $4.5 \times 10^{7}$ with an average of $2.1 \times 10^{6} \pm 1.5 \times 10^{6}$ for sausage and $1.1 \times 10^{5}$ to $6.2 \times 10^{5}$ with an average of $2.9 \times 10^{5} \pm 2.6 \times 10^{4}$ for luncheon respectively.

According to the safe permissible limit stipulated by ESO (2005) No (1090-2005) for APC in meat which was (not exceed $10^{5}$ and $10^{6} \mathrm{cfu} / \mathrm{g}$ ), it was indicated that most of the examined samples come in accordance with this limit in corresponding to meat samples. Similar results were recorded by Fliss et al. (1991) $\left(3 \times 10^{5}\right)$ 
however lower result were recorded by Eltaher (2009) $\left(8.17 \times 10^{4}\right)$ and Arab (2010) $\left(2.4 \times 10^{5}\right)$, Higher results recorded by Mansour (1995) $\left(5.72 \times 10^{5}\right)$ and Hashem (2015) (6.18 $\left.0.67 \log 10\right)$.

Table (2) indicated that total anaerobic plate count of the examined samples of vacuum packaged meat products was $1.1 \times 10^{5}$ to $7.1 \times 10^{7}$ with an average of $1.5 \times 10^{7} \pm 3.5 \times 10^{6}$ for sausage and $1.2 \times 10^{5}$ to $4.2 \times 10^{5}$ with an average of $2.4 \times 10^{5} \pm 2.5 \times 10^{4}$ for luncheon respectively. Lower result was recorded by (Hassan, 2009) $\left(8.7 \times 10^{3}\right)$.

Food sometimes contains bacteria: of uncertain significance to human health, some of these bacteria belong to the normal intestinal flora of man and animals and many of them appear as food contaminants which lead to food spoilage (Warries, 2000).

Table (3) reported the total Enterobacteriacea count of the examined samples of vacuum packaged meat products varied from $3.6 \times 10^{2}$ to $7.8 \times 10^{4}$ with an average $1.7 \times 10^{4} \pm 3.9 \times 10^{3}$ for sausage and $1.1 \times 10^{5}$ to $3.5 \times 10^{5}$ with an average $2 \times 10^{5} \pm 2 \times 10^{4}$ for luncheon samples. Nearly similar results were receded with Hussein (1996) (1.9x10 $)$ , and Daif (1996) $\left(1 \times 10^{5}\right)$, Lower results found by Hassan. (2015) $\left(2.2 \times 10^{4} \pm 9.4 \times 10^{3}\right)$, Capita et al. (2002) $\left(3.38 \times 10^{3}\right)$ But Hashem. (2015) (3.91 0.96 $\log 10)$, and Vural $(2007)\left(6.03 \times 10^{5}\right)$ recorded higher results.

High Enterobacteriacea count was more recorded in meat mainly due to contamination. It begins from the point of slaughtering until receiving of meat. Improper cooking does not kill chicken and all microorganisms and keeping this food in improper temperature leading to growth and proliferation of pathogenic organisms including Enterobacteriacea group members.

The presence of Enterobacteriaceae in meat indicates a microbial proliferation, which could allow a 'multiplication of pathogenic and toxigenic microorganisms constituting a public health hazard (ICMSF, 1978).

Figure (1) demonstrated the comparison between percentage of APC, anaerobic plate count and the Enterobacteriacea count for all examined samples of vacuum packaged meat products of sausage and luncheon It is appeared that total APC in $100 \%$ of all examined samples of vacuum packaged meat products of sausage and luncheon and followed by total Enterobacteriacea account which appear by $73.3 \%$ in sausage and $66.6 \%$ in luncheon then total anaerobic appear by $60 \%$ in sausage and $70 \%$ in luncheon.
From this comparison, it is clear appeared that contamination was occurred

Tables (4) revealed that the incidence and serotyping of Salmonella isolated from the examined samples by $10 \%$ for sausage and $3.3 \%$ for luncheon. Table (5) was identified serologically as S.typhimurium (1\%) and S.entretidis (2\%) . Results nearly similar to resulted recorded by Mansour (1995), and Khallaf (2014). But higher results reported by (Arumugaswamy et al., (1993) and Hashem. (2015). Lower results were recorded by Jordan, et al (2006). These results agree with Khallaf (2014), Hashem (2015) and others and disagree with Ouf (2001), Reham (2004) and Arab (2010) .

Salmonellosis is a great problem and important food born disease. Mishandling in preparation of food of animal origin was the major reason for the outbreak of Salmonellosis (Rachimanin and Koulikouskii, 1990). The number of human cases of Salmonellosis increased due to serious hygienic diffeciancy in a food technology during processing, production and storage of food as well as due to poor hygiene of a personal working (Koutikoyski and Kasijanenko,1991).

Table (5) referred to the C.perfringens isolated from the examined vacuum packaged meat samples with $33.3 \%$ for sausage and with $43.3 \%$ for luncheon. Nearly similar results were obtained by Hassan (1998) while, Higher results recorded by Gutierrez et al (1999) and lower than by Miwa et al. (1998). These results agree with Shlatout (1999) and Atwa and EL-Roos (2011) and disagree with Hashem (2015) who not detect C.perfringens.

Labbe (2000) reported that processed meat was important as the most common food vehicle of $C$. perfringens type A food poisoning.

Table (6) reported the incidence of Lecithinase $+v e$ strains in the examined samples of sausage were 7 of $10(70 \%)$ of C. perfringens and Lecithinase -ve strains were 3 of $10(30 \%)$.

Lecithinase +ve strains of $C$. perfringens in the examined samples of luncheon were 10 of 13 (77\%) and Lecithinase -ve strains were 3 of 13 (23\%).

It is noticed that there was a contamination and recontamination with C.perfringns in meat meals either before and after cooking especially in the presence of a lot of worker hands that dealing with handling cutting and preparing of the meat meals in a place serving a large number of people in a certain time. 
The results reported in table (7) showed that +ve lecithinase strains of C.perfringens isolates were typing into type A,B,C and D toxins. Type A appeared in $70 \%$ of +ve Lecithenase in sausage samples and $100 \%$ in luncheon samples and B, C, $\mathrm{D}$ not detected. The results agree with Labbe (2000) who had demonstrated that raw meat and processed one were important as the most common food vehicle of $C$. perfringens type $A$ food poisoning.

Tables (4) reported that Staph aureus was isolated from $6.6 \%$ for sausage and $10 \%$ for luncheon, respectively. These results nearly similar to Arab (2010) while higher results were achieved by Hashem (2015) and El Taher (2009) and lower results were recorded by Lotfi (1990).

Concerning to the obtained results, it could be concluded that raw meat samples were the most contaminated with $S$. aureus than other samples. This may reflect a bad hygienic practice during different stages from slaughtering, handling practices transportation and excessive handling during preparation of meals. A presence of this microorganism in post processing meat meal indicated that post processing contamination occur.

Contamination with $S$. aureus is an important risk index in evaluation of safety and hygienic quality of chicken meat (Jyhshiun et al.,2009). The presence of $S$ aureus in heat treated food may be due to its contamination from food handlers, inadequate cleaned equipment or post processing contamination (Duffy et al.,2000).

Staphylococcus. aureus present on the nose and skin can be transferred to foods by handling. Subsequent storage enables growth and toxin production by the organisms (Roberts, 1990).

The obtained results in the current study concluded that the examined vacuum packaged meat product samples (sausage- luncheon) exposed for contamination during processing from point of slaughtering, handling, transportation, storage until to receiving which increased its contamination. Cooking especially boiling plays a great role in killing of most of these microorganisms

\section{REFERENCES}

Aberel, E.D., Forrest, J.C., GerrardD, E., Mllls, E.W., 2001. Principles of Meat Science. 4th Ed. Kendall/Hunt Pubi. Co. Dubuque, IA.

APHA., 2001. American puplic Health Association. Compendium of methods for the microbiological examination of food 4
thEd. Aguafind.comlarticles/Value Added fish-process.-ph-p.

Arab, W., 2010. Quality improvement of meat meal in University restaurant.D.V. SC. ,Thesis,fac.Vet.Med.,Benha University.

Arumugaswamy, R.K., Rusul, G., Abdul Hamid, S.N., Cheah, C.T.J., 1995. Prevalence of Salmonella in raw and cooked foods in Malaysia. Food Microbiol. 12, 3-8.

Atwa, E., Land El-Roos, N.A., 2011. Incidence of Clostridiui perfringens in meat products at some Egyptian Governorate International Journal of Microbiological Research 2, 196203.

Bhatia, A., Zahoor, S., 2007. Staphylococcus enterotoxins: Areview J. Clinical and Diagnostic Res., 1:188-197. Brett,M.M.and Gilbert,R.J.(1997):1566 outbreaks of C.perfringens food poisoning( 1970-1996). Rv.Med.Microbiol.,8 suppl. 81.

Capita, R., Alonoso-Calleja, C., Garcia-Arias, M.T., MOreflo, B., M., D.C.G.-f., 2002. Methods to detect the occurance of various indicator bacteria on the surface of retail poultry in Spain. J. Food Sci. 67, 771.

Daif, E.A., 1996. Sanitary status of meat of the students of EL-Azhar University "Assiut Branch" M.V.Sc. Thesis, (Meat Hygiene), Fac. Of Vet. Med., Assiut University.

EL-Taher, A.M., 2009. Impact of temperature abuse on safty of food offerd in University Student Resturant M.V.Sc. Thesis( Meat hygiene), fac. of Vet.Med.Benha Uni.

Fliss, I., Simrad, R.E., Eltriki , A., 1991. Microbial quality of different fresh meat species in Tunisean slaugher houses and markets. J.Food Prot. 54, 773-777.

Gutirrrez, A.M., Gamboa, M.d.R., Arias, M., 1999. Presence of $\mathrm{C}$. perfringens in meat based preparation from public food services in San Fose, Costa Rico. Archives latinoameri canos de nutricion 49, 275-278.

Hashem, H.M.S., 2015. Bacteriological criteria of .dressed poultry with special reference to some microbial decontaminantors, Thesis (Meat Hygiene) ,Benha Uni.

Hassan, A.S.O., 2015. Microbiological status of poultry carcases from retailed outlets in Alex. province.Fac.ofVet.Med.,Alex.Uni.

Hassan, H., 2009. Colistridial species and related organisms in meat and meat products .Meat Hygiene .Benha University.

Hussein, M.I., 1996. Microbial evaluation of some meat meals of Assiut restaurants. M. V. Sc. Thesis,. Fac. Of Vet. Medicine, Assiut University. 
ICMSF, 1978. (International Comission on Microbiological Spesificans for foods ). "Microorganisms in foods". 1- their significance and Methods of Enumeration, 2' Ed. Univ. of torontopress . Toronto.

ICMSF, 1996. International Comission on Microbiological Spesificans for foods. Salmonella In. Roberts, TA., Baired parker, iejerriCe.

ICMSF, 2006. (International Comission on Microbiological Spesificans for foods) Microorganism in foods, Microbiol ecology of food commodities. 2 ed. Klumer Academics, plenum publishers. londers, U.K.

ISO, 2004. International Organization of Standerdization No.1129-1. Microbiology of food and animal feeding stuffs-Horizontal methods for detection and enumeration of Enterobacteriacea part2 ;colony count.method.

Jordan, E., Ega, J., Dullea, C., Ward, J., Mc Gillicuddy, K., Murray, G., Murphy, A., Bradshaw, B., Leonard, N., Rafter, P., Mc Dowell, S., 2006. Salmonella surveillance in raw and cooked meat and meat products in the republic Ireland from 2002 to 2004. Int. J. Food MicrobioL. 20.

Jyhshiun, L., Kuang Sheng, Y., Hsush Tao, L., Jiun Horng, I., 2009. Staph aureus isolated from pork and chicken carcasses in Taiwan; prevalence and antimicrobial, susceptibility,. J. Food protect. 72, 608-611.

Khallaf, M., Ameur, N., Terta, M., Lakranbi, M., Senoudil, S., Ennaji, M.M., 2014. Prevalence and antibiotic resistance of Salmonella isolated from chicken meat marketed in Rabat,Morcoo.

Koutikoyski, A., Kasijanenko, A.L., 1991. Present status of Salmonellosis in the Soviet union WHO collaborating center for Veterinary Sanitation and Food Hygiene, Moscow, USSR.

Labbe, R.G., 2000. C. Perfringens. In: Lund, B., Baird Parker, T Gould, and G. publishers, MD, USA, pp. 1110-1135.
Lotfi, Y.A., Youssef, E.K., 1966. Comparative study Concerning chemical and bacteriological evaluations of locally manufactured and imported dry and semidry Sausage.

Mansour, W.M., 1995. Organoleptic and microbial examination of beef and chicken received at a Governmental Hospital kitchen. M. V. Sc. Thesis, Meat Hygiene, Fac. of Vet .Med. Zagazig Univ. Benha branch'.

Miwa, N., Nishina, T., Kubo, S., Atsumi, M., Honda, H., 1998. Amount of Enterotoxigenic C. perfringens in meat detected by Nested PCR. Inter. J. Food Microbiol. 42, 195-200.

Ouf, J.M., 2001. Microorganisms of Sanitary importance in some meat products - and Their additives. Ph. D. Thesis (Meat Hygiene), Fac. Vet. Med., Cairo University.

Rachmanin, P., Koulikoviskii, A., 1990. Epidemiology of Salmonellosis and preventive measures in the USSR. . Veterinarya 10, 40-44.

Reham, A.A., 2004. Microbial evaluation of some meat products. M. V .Sc. Thesis (Meat hygiene); Fac. Vet. Med., Moshtohor, Zagazig University. (Benha Branch).

Roberts, D., 1990. Sources of infection: food. . Lancet British Edition 336, 859-861.

Roberts, D., Hooper, W., Greenwood, M., 1995. Practical food microbiology. Puteler and Taner, London.

Shaltout, F.A., 1999. Anaerobic bacteria in vacuum packed meat products. . Benha Vet. Med. J. 10, 1-10.

Vural, A., Erkan, M.E., Yesllnie, S., 2007. Microbiological quality of retail chicken carcasses and their products in Turkey. Medycna Wet. 62, 1371-1374.

Warries, P.D., 2000. Meat Science. 1 st Ed. CABI publishing co. CABI. International, Walling Ford,United Kingdom. Weineke, A.A.,; Roberts, D. and Gilbert, R. J. (1993): Staphylococcal. 